\title{
IMPLEMENTASI KEBIJAKAN PEMUNGUTAN PAJAK HOTEL DAN PENGINAPAN DI KABUPATEN SINTANG PROVINSI KALIMANTAN BARAT
}

\author{
THE POLICY IMPLEMENTATIONS HOTEL AND LODGING TAXES REVENUE IN \\ SINTANG REGION IN WEST KALIMANTAN PROVINCE
}

Oleh :

\author{
TRESIA KRISTIANA
}

\begin{abstract}
ABSTRAK
Penelitian ini tentang Implementasi Kebijakan Pemungutan Pajak Hotel dan Penginapan, terdapat berbagai model yang dapat mendukung pelaksanaan kebijakan guna meningkatkan Pendapatan Asli Daerah dari sektor pajak daearah, terindikasi hasil pemungutan yang dilakukan mengalami fluktuasi sehingga hasil pungutan pajak belum optimal, serta belum dapat dijadikan sebagai sumber keuangan daerah, untuk membiayai kegiatan pemerintahan daerah dan pembangunan yang seharusnya digali dari potensi sumber daya daerah yang dimiliki.

Penelitian ini menggunakan metode deskriptif kualitatif. Teknik pengumpulan data dilakukan dengan mengumpulkan data primer dan sekunder melalui wawancara dan observasi, untuk data sekunder didapatkan dari dokumen resmi, berupa laporan kegiatan dan Peraturan perundangundangan yang berlaku.

Hasil penelitian menunjukan bahwa beban kerja staf pelaksana dalam mengimplementasikan kebijakan melebihi kemampuannya, insentif masih minim namun telah diatur dalam Peraturan Daerah Nomor 5 Tahun 2009, disisi lain standar tujuan kebijakan telah ada dan diatur dalam Peraturan Daerah tentang Satuan Organisasi Perangkat Daerah. Komunikasi internal dan eksternal cukup efektif, lingkungan sosial, ekonomi, politik cukup mendukung, sehingga hasil dari pemungutan Pajak Hotel dan Penginapan mengalami peningkatan dilihat dari pencapaian target dan realisasi meskipun belum signifikan peningkatannya jika dibandingkan dengan potensinya.

Temuan dari penelitian ini adalah adanya faktor lain yang mempengaruhi keberhasilan implementasi kebijakan yaitu sistem kerja merupakan pengembangan dari teori implementasi kebijakan menurut Van Meter dan Van Horn yaitu dimensi standar.
\end{abstract}

Kata Kunci : Implementasi kebijakan, Pajak Hotel dan Penginapan.

\begin{abstract}
This research examinies on the policy Implementation Hotel and Lodging Taxes. There are various models that can support the implementation of policies to improve local revenue from affluent sectors tax. Poll results indicated to be fluctuate so that tax money is not optimal, and can not be used as an area's finance resources, to fund local government activities and development which should be extracted from the area's potentialresouces.
\end{abstract}

This study used a qualitative descriptive method. data collection technicque conducted by collectingprimary and secondary data through interviews and observation. Secondary data obtained from official documents, activities and report and applicable regulations. 
The results showed that the operating staff workload exceeds the ability to implement policies, incentives are still low but has been regulated in Local Regulation No. 5 of 2009, on the other hand there are standards and policy objectives have been set in the Regulation on Organization of the regional units. Internal and external communication is effective, the social environment, economy, politics quite supportive, so that the results of the poll tax Hotel and Lodging seen increased realization of the achievement of targets and although not significant increase when compared to its potential. The findings of this study is the presence of other factors that influence the successful implementation of policies that work is the development of systems theory of policy implementation by Van Meter and Van Horn is a standard dimension.

Keywords: Implementation of policies, Hotel and Lodging Tax.

\section{PENDAHULUAN}

Keleluasaan daerah dalam memungut pajak dan retribusi daerah diharapkan dapat meningkatkan kemampuan daerah dalam melaksanakan otonomi daerah, dengan ditunjang oleh kesadaran masyarakat yang tinggi dalam membayar pajak. Pendapatan Daerah dari pajak daerah dapat ditingkatkan dengan meningkatkan efisiensi pemungutan dan efisiensi administrasi pajak serta perbaikan kontrol terhadap petugas pemungutan dalam rangka mengurangi kebocoran.

Pemungutan pajak daerah, di Pemerintah Daerah Kabupaten Sintang diatur dengan Peraturan Daerah Kabupaten Sintang Nomor 5 Tahun 2003 tentang Pajak Hotel dan Penginapan yang ditetapkan pada tanggal 29 Desember 2003, Peraturan Daerah ini masih berlaku hingga saat ini.

Dari berbagai jenis pajak yang ada dalam penelitian ini peneliti akan fokus pada Pajak Hotel dan Penginapan. Pemungutan Pajak Hotel dan Penginapan di Kabupaten Sintang Provinsi Kalimantan Barat dilakukan dengan ketentuan yang berlaku dalam Peraturan Daerah Kabupaten Sintang Nomor 5 Tahun 2003 Tentang Pajak Hotel dan Penginapan.

Berkaitan dengan penyelenggaraan otonomi daerah terutama untuk membiayai penyelenggaraan otonomi daerah (desentralisasi fiscal) pemerintah daerah dapat menggali sumbersumber penerimaan bagi daerah dengan potensi masing-masing daerah. Salah satu Pajak daerah yang dapat digali menjadi sumber Pendapatan asli daerah adalah pajak hotel dan penginapan. Di Kabupaten Sintang Pajak Hotel dan Penginapan setiap tahun mengalami fluktuatif dalam pencapaian target, dikarenakan penetapan target belum dilakukan dengan perhitungan yang akurat, dengan memperhitungkan potensi pajak yang sebenarnya, perhitungan yang dilakukan hanya didasarkan pada pendapatan tahun sebelumnya dengan tambahan kenaikan sebesar $10 \%$ setiap tahun.

Pelaksanaan pemungutan Pajak Daerah di Kabupaten Sintang, khususnya Pajak Hotel dan Penginapan di tetapkan dengan Peraturan Daerah Nomor 5 Tahun 2003, standar dan sasaran kebijakan yang dibuat oleh Dinas Pendapatan Pengelolaan Aset dan Keuangan Daerah diatur dalam Rencana Kerja Dinas ini, dalam bentuk rencana strategi yang memuat rencana kinerja, capaian kinerja dan analisis capaian kinerja. Rencana Strategis menjadi acuan dan pedoman dalam melaksanakan tugas dan fungsi dinas, sesuai dengan ketentuan yang ditetapkan oleh Bupati sebagai Kepala Daerah, dalam Susunan Organisasi Tata Kerja Dinas Pendapatan Pengelolaan Keuangan dan Aset Daerah, dalam pelaksanaannya masih terdapat kendala-kendala yang dihadapi terutama dalam melaksanakan tugas dan fungsi salah satunya dalam mengimplementasikan kebijakan tentang Pajak Hotel dan Penginapan. 
Dalam pelaksanaan Implementasi Kebijakan Pemungutan Pajak Hotel dan Penginapan yang dilakukan oleh Pemerintah Daerah Kabupaten Sintang, dengan menggunakan model implementasi kebijakan menurut Donald Van Meter dan Carl E.Van Horn, dimana terdapat enam variabel yang membentuk hubungan antara kebijakan dengan pelaksana. Keenam variabel terdiri dari : 1)standar dan tujuan (standard and objectivitas), 2) sumber daya (resources), 3)komunikasi antar organisasi (comunications and enforcement activities), 4)karakteristik agen pelaksana (the characteristic of the implementing agencies), 5)kondisi sosial ekonomi dan politik (economic, social and political conditions) 6)disposisi pelaksana (the disposition of implementory).

Peraturan Daerah Kabupaten Sintang Nomor 5 Tahun 2003 tentang Pajak Hotel dan Penginapan, merupakan salah satu kebijakan publik, sebagaimana pendapat Santoso (1993:4) pandangan mengenai kebijakan publik dapat dibagi kedalam dua wilayah katagori salah satunya, pendapat para ahli yang menyamakan kebijakan publik dengan tindakan-tindakan pemerintah. Dalam penelitian ini tidakan pemerintah Kabupaten Sintang dengan menerbitkan Peraturan Daerah Nomor 5 Tahun 2003 tentang pemungutan Pajak Hotel dan Penginapan adalah merupakan implementasi kebijakan.

Sebagaimana menurut pendapat Anderson yang dikutif oleh Tachjan (2008:16) \|Public polices are those policies developed by governmental bodies and officiall. Maksudnya kebijakan publik adalah kebijakan-kebijakan yang dikembangkan oleh badan-badan dan pejabat-pejabat pemerintah. Kebijakan Pemungutan Pajak Hotel dan Penginapan di Kabupaten Sintang yang diatur dalam Peraturan Daerah Kabupaten Sintang Nomor 5 Tahun 2003 adalah kebijakan yang dikembangkan oleh Pemerintah Kabupaten Sintang dalam hal ini Bupati Sintang.

Peraturan Daerah Kabupaten Sintang Nomor 5 Tahun 2003 tentang Pajak Hotel dan Penginapan dikatakan sebagai suatu kebijakan sebagaimana pendapat Edward dan Sharkansky yang dikutip oleh Islamy (1992:18-19) kebijakan dapat ditetapkan secara jelas dalam bentuk peraturan perundang-undangan, pidato-pidato pejabat teras pemerintah ataupun dalam bentuk programprogram, proyek-proyek dan tindakan-tindakan yang dilakukan pemerintah. Mengacu pada pendapat tersebut maka dapatlah dikatakan bahwa peraturan daerah yang telah ditetapkan oleh Pemerintah Daerah Kabupaten Sintang tersebut merupakan sebuah kebijakan.

Kebijakan Pemungutan Pajak Hotel dan Penginapan yang telah dikeluarkan oleh Pemerintah Daerah Kabupaten Sintang, yang telah ditetapkan dan di Undangkan dalam Lembaran Daerah Kabupaten Sintang Tahun 2003 Nomor 26 Seri B Nomor 2,oleh Sekretaris Daerah Kabupaten Sintang, Peraturan Daerah sebagaimana dimaksud dalam penelitian ini merupakan suatu kebijakan publik, sebagaimana menurut Tachjan (2008:16) dalam suatu negara kebijakan publik tersusun dalam suatu strata yang menunjukan tingkatan-tingkatan dari kebijakan paling tinggi yang sifatnya paling strategis sampai pada kebijakan yang paling rendah yang sifatnya teknis operaional. Kebijakan yang lebih rendah merupakan penjabaran dari kebijakan yang paling tinggi dan materinya tidak boleh bertentangan. Demikian juga halnya kebijakan Pemerintah Daerah Kabupaten Sintang Nomor 5 Tahun 2003 tentang Pajak Hotel dan Penginapan ini tidak bertentangan dengan Peraturan PerundangUndangan yang diatasnya yakni Undang-Undang Nomor 34 Tahun 2000 tentang Pajak Daerah dan Retribusi Daerah dan Peraturan Pemerintah Nomor 65 Tahun 2001 tentang Pajak Daerah. Peraturan ini tentu tidak bertentangan karena dilakukan penyempurnaan dan penyesuaian, dimana dalam peraturan tersebut ada pemisahan obyek pajak antara hotel dan penginapan.

Implementasi kebijakan merupakan salah satu tahapan yang penting dalam proses kebijakan, implementasi kebijakan juga merupakan alat administrasi hukum karena sebagai aktor, organisasi, prosedur dan teknik untuk menjalankan kebijakan guna mencapai tujuan yang ingin dicapai. Peraturan Daerah Kabupaten Sintang Nomor 5 Tahun 2003 merupakan payung hukum untuk 
pelaksanaan pemungutan Pajak Hotel dan Penginapan, dimana Pajak tersebut merupakan salah satu Sumber Pendapatan Asli Daerah yang akan memberikan kontribusi dalam kegiatan pembangunan. Sebagaimana pendapat Syamsi (1988:228) sumber pendapatan asli daerah tersebut adalah pajak daerah dan retribusi daerah sangat penting, karena merupakan sumber pendapatan asli daerah yang paling besar. Hasil dari pungutan pajak daerah dapat dijadikan sebagai sumber untuk membiayai pelayanan kepada masyarakat.

Tujuan dari pemungutan pajak adalah sebagai upaya untuk meningkatkan pendapatan guna membiayai operasional pemerintah, untuk mengatur perekonomian dan pencapaian tujuan sosial lainnya dalam mencapai kesejahteraan bagi masyarakat. Untuk dapat mencapai kesejahteraan bagi masyarakat, pemerintah harus dapat menjalankan roda pemerintahan, terutama pelaksanaan pembangunan. Pembangunan yang dilakukan membutuhkan biaya yang cukup besar, salah satu sektor yang dapat diandalkan untuk membiayai kegiatan pembangunan tersebut adalah pajak daerah. Pembangunan yang sedang dan akan dilaksanakan agar dapat mencapai tujuan yang diinginkan maka harus didukung oleh pengelolaan di sektor pajak. Masyarakat harus mendukung dengan kesadaran yang tinggi untuk membayar pajak, karena hasil pungutan pajak tersebut diperuntukan untuk kepentingan masyarakat.

Kesadaran masyarakat untuk membayar pajak, termasuk pajak daerah ditentukan dari ketegasan pemerintah dengan membuat peraturan-peraturan, yang mengacu pada Undang-Undang yang berlaku. Sebagaimana yang diatur dalam Undang-Undang Nomor 34 Tahun 2000, Pajak Daerah adalah iuran wajib yang dilaksanakan oleh orang pribadi atau badan kepada daerah tanpa imbalan langsung yang seimbang, yang dapat dipaksakan berdasarkan peraturan perundang- undangan yang berlaku, yang digunakan untuk membiayai penyelenggaraan pemerintah daerah dan pembangunan daerah. Sejak bergulirnya Otonomi Daerah maka tanggungjawab pemerintah daerah semakin berat karena dituntut kemandirian untuk mampu mencari dan menggali potensi yang dimiliki dalam hal pendanaan kegiatan pemerintahan dan pembangunan. Sebagaiman pendapat Norton 1994 dan Smith,1985 (dalam Nugroho,2007:153) kemandirian daerah memutuskan pengeluaran guna menyelenggarakan layanan publik dan pembangunan, dan kemandirian daerah memperoleh pendanaan guna pembiayaan pembangunan.

Ada beberapa variabel Menurut Van Meter dan Van Horn yang menjadi faktor yang mempengaruhi atau dimensi yang terdapat dalam implementasi yang diarahkan pada pencapaian tujuan. Adapun variabel tersebut:

\section{Standar dan Tujuan}

Peraturan Daerah Nomor 5 Tahun 2003 tentang Pajak Hotel dan Penginapan diundangkan di Sintang pada tanggal 30 Desember Tahun 2003, oleh Sekretaris Daerah Kabupaten Sintang tertanda Drs. Wasbir Martha,MM dalam lembaran Daerah Kabupaten Sintang Tahun 2003 Nomor 26 Seri B. Nomor 2.

Tahapan dalam pelaksanaan implementasi kebijakan pemungutan Pajak Hotel dan Penginapan yang dilakukan setelah Pemerintah Daerah Kabupaten Sintang menetapkan Peraturan Daerah Nomor 5 Tahun 2003, tentang Pajak Hotel dan Penginapan. Peraturan Daerah ini mengacu pada Undang-Undang Nomor 34 tahun 2000 tentang Pajak Daerah dan Retribusi Daerah berikut tentang peraturan pelaksananya yaitu Peraturan Pemerintah Nomor 65 tahun 2001 tentang Pajak Daerah dimana esensi peraturan tersebut mengamanatkan obyek pajak berupa Hotel dapat dikenakan dengan Pajak Daerah yang diatur dengan Peraturan Daerah. Meskipun saat ini UndangUndang tersebut telah mengalami perubahan dengan diterbitnya Undang-Undang Nomor 28 tahun 2009 tentang Pajak dan Retribusi Daerah, namun di Kabupaten 
Sintang tetap menggunakan Peraturan Daerah Nomor 5 Tahun 2003, dalam pelaksanaan pemungutan Pajak Hotel dan Penginapan.

Pelaksanaan Pemungutan Pajak yang telah ditetapkan oleh Pemerintah Daerah Kabupaten Sintang adalah Dinas Pendapatan dan Pengelolaan Keuangan dan Aset Daerah (DPPKA), hal ini mengacu pada Keputusan Bupati Sintang Nomor: 02 Tahun 2008 Lembaran Daerah Tahun 2008 Nomor 02 Tambahan Lembaran Daerah Nomor 02 tentang Susunan Organisasi Pemerintah Daerah. DPKKA merupakan unsur pelaksana teknis di bidang pendapatan, pengelolaan keuangan dan Aset. Sebagai unsur teknis DPPKA Kabupaten Sintang mempunyai tugas dan fungsi sebagi berikut:

a. Tugas

Dinas Pendapatan, Pengelola Keuangan Dan Aset Kabupaten Sintang sebagai unsur penunjang mempunyai tugas melaksanakan sebagian kewenangan Pemerintah Kabupaten di bidang Pendapatan, pengelolaan keuangan dan Aset serta tugas kedinasan lainnya yang dilimpahkan oleh Bupati.

b. Fungsi

Untuk menyelenggarakan tugas tersebut di atas, Dinas Pendapatan, Pengelola Keuangan dan Aset mempunyai beberapa fungsi, untuk fungsi yang berhubungan dengan penelitian ini yaitu implementasi kebijakan pemungutan pajak hotel dan penginapan adalah:

1. Perumusan kebijakan teknis dibidang pendapatan, Pengelola Keuangan Dan Aset;

2. Penyusunan dan pelaksanaan rencana strategis dan rencana kerja tahunan dibidang pendapatan, Pengelola Keuangan Dan Aset;

3. Penyusunan Penetapan Kinerja dibidang Pendapatan, Pengelola Keuangan Dan Aset;

4. Pembinaan Unit Pelayanan Terpadu Daerah dibidang Pendapatan;

5. Evaluasi dan laporan pelaksanaan tugas dan fungsi;

6. Pelaksanaan Standar Pelayanan Minimal (SPM) dibidang Pendapatan, Pengelolaan Keuangan Dan Aset;

7. Penyusunan Laporan Akuntabilitas Kinerja Instansi Pemerintah dibidang Pendapatan, Pengelolaan Keuangan Dan Aset;

Sesuai dengan tugas dan fungsinya, Dinas Pendapatan, Pengelola Keuangan Dan Aset Daerah Kabupaten Sintang setiap tahun akan menetapkan Rencana Kerja untuk satu tahun kedepan yang akan dijadikan pedoman dan dasar pelaksanaan kegiatan pokok maupun penunjang di bidang Pendapatan, Pengelola Keuangan dan Aset Daerah. Pedoman dan dasar pelaksanaan tersebut merupakan standar dan sasaran dari kebijakan pemungutan pajak daerah yang dilakukan di Pemerintah Daerah Kabupaten Sintang.Dalam melaksanakan tugas pokok dan fungsi Kepala Bidang Pendapatan dibantu oleh : (1) Seksi Pendaftaran dan Pendataan (2) Seksi Penetapan (3) Seksi penagihan

Standar dalam memberikan pelayanan Pajak Daerah khususnya Pajak Hotel dan Penginapan di Kabupaten Sintang menurut Kepala Dinas Pendapatan Pengelolaan Keuangan dan Aset Daerah (DPPKA) Kabupaten Sintang disesuaikan dengan ketentuan yang berlaku, yang dikeluarkan oleh Kementrian Keuangan Republik Indonesia yakni berupa standar prosedur operasi (Standard Operating Procedure) layanan unggul bidang perpajakan meliputi : 1) Pelayanan penyelesaian permohonan pendaftaran nomor pokok wajib pajak, sebagai identitas untuk melaksanakan hak dan kewajiban perpajakan, 2) pelayanan penyelesaian permohonan pengukuhan wajib pajak, 3) pelayanan penyelesaian permohonan pengembalian kelebihan pembayaran pajak, 4) pelayanan penerbitan surat perintah membayar kelebihan pajak, 5) pelayanan penyelesaian permohonan keberatan penetapan pajak, 6) pelayanan penyelesaian surat keterangan bebas pemungutan, 7) 
pelayanan penyelesaian permohonan pengurangan, 8) pelayanan pendaftaran objek pajak baru dengan penelitian kantor, 9) pelayanan penyelesaian mutasiseluruh objek dan subjek pajak, 10) pelayanan penyelesaian permohonan keberatan pajak, 11) pelayanan penyelesaian permohonan pengurangan atau penghapusan sanksi administrasi, 12) pelayanan penyelesaian permohonan pengurangan atau pembatalan ketetapan pajak yang tidak benar.

Dari data yang penulis dapatkan baik hasil wawancara maupun dokumentasi yang ada menunjukan bahwa dalam mengimplementasikan kebijakan pemungutan Pajak Hotel dan Penginapan yang dilakukan oleh Dinas Pendapatan Pengelolaan Keuangan dan Aset Daerah Kabupaten Sintang telah dilakukan sesuai dengan pendapat dari Donald.S Van Meter dan Carl.E Van Horn (1975:462) yang mengutif pendapat dari Pressman and Wildavsky(1973:xiv) In determining standard and objectives one could use the statement of policy maker, as reflected in numerous documents such as program regulations and guidelines which spell out the criteria for an evaluation on policy performance.

Standar dan tujuan kebijakan Van Meter dan Van Horn sebagaimana dikutip oleh Widodo (2001:197-198) harus senantiasa dicantumkan dengan jelas ditiap-tiap program, jika standar dan tujuan kebijakan itu jelas maka akan dengan mudah untuk dilaksanakan, sebaliknya akan sering terjadi kegagalan bila standar dan tujuan tidak jelas.

Pelaksananya kebijakan tentang pemungutan pajak daerah tersebut sebagaimana ditetapkan oleh Keputusan Bupati Sintang adalah Dinas Pendapatan Pengelolaan Keuangan dan Aset Daerah (DPPKA) Kabupaten Sintang, hal ini termuat dalam Pasal 5 Peraturan Bupati Sintang Nomor 39 Tahun 2008 tentang Susunan Organisasi dan Tata Kerja (SOTK) pada Dinas Pendapatan, Pengelolaan Keuangan dan Aset Kabupaten Sintang. Tugas pokok DPPKA adalah melaksanakan sebagian kewenangan otonomi daerah dibidang pendapatan, pengelolaan keuangan dan aset.

Adapun pernyataan misi Dinas Pendapatan, Pengelolaan Keuangan dan Aset Kabupaten Sintang adalah: a) Meningkatkan penerimaan daerah. b) Memantapkan Sistem Pengelolaan Pendapatan, Keuangan dan Aset /Kekayaan/ Barang Daerah. c) Meningkatkan kualitas pelayanan.

Dalam mengimplementasikan kebijakan Pemerintah Daerah, khususnya Pajak Hotel dan Penginapan sesuai dengan kewenangan dalam tugas pokok dan fungsinya Dinas Pendapatan Pengelolaan Keuangan dan Aset Daerah Kabupaten Sintang, telah melakukan prosedur pelayanan pemungutan pajak, namun hasil yang didapat belumlah maksimal menujukan dukungan terhadap peningkatan Pendapatan Asli Daerah yang akan digunakan untuk membiayai kegiatan pembangunan.

Menurut Brotodihardjo (2006:113) tata cara pemungutan pajak dapat dilakukan dengan tiga stelsel yakni (1) Stelsel nyata, (2) Stelsel anggapan, (3) stelsel campuran.

\section{Sumber Daya (resources)}

Sumber daya sebagaimana yang dimaksud Van Meter dan Van horn mencakup dana atau perangsang (incentive) yang dapat mendorong dan memperlancar proses implementasi kebijakan secara efektik. Sumber daya dapat juga berupa aparat pelaksana (staff), informasi, kewenangan dan fasilitas sebagaimana yang dikutif dari pendapat Edwards III.

Uang perangsang (insentif) sebgai bagian dari sumber daya, telah diatur oleh Pemerintah Daerah dan ditetapkan dalam Peraturan Daerah Kabupaten Sintang Nomor 5 Tahun 2009 tentang Pemberian Uang Perangsang Kepada Unit Kerja Yang Melaksanakan Pemungutan Pajak Daerah. Untuk Pemungutan Pajak Hotel dan Penginapan karena pelaksananya adalah Dinas Pendapatan 
Pengelolaan dan Keuangan Aset Daerah, maka uang perangsang diberikan kepada staf pelaksana yang melakukan pemungutan Pajak Daerah Tersebut.

Pemberian uang perangsan ini ditujukan untuk meningkatkan kesejahteraan dan memotivasi pegawai pada unit kerja yang melaksanakan pemungutan pajak daerah dalam rangka menunjang pendapatan daerah. Adapun bersarnya uang perangsang yang diterima selama kurun waktu tiga tahun dari tahun 2006, tahun 2007, tahun 2008, tahun 2009 dan tahun 2010 adalah sebagai berikut :

Tabel.4.10

Hasil Perhitungan Uang Perangsang Yang Diterima DPPKA dari Pajak Hotel dan Penginapan

\begin{tabular}{|c|l|l|l|l|}
\hline No & Tahun & $\begin{array}{l}\text { Realisasi Penerimaan Pajak } \\
\text { Hotel dan Penginapan }\end{array}$ & Jumlah Uang Perangsang & \multicolumn{1}{|c|}{$\begin{array}{c}\text { Peningkatan Uang } \\
\text { Perangsang }\end{array}$} \\
\hline 1. & 2006 & Rp. $140.589 .175,00$ & Rp. $7.029 .458,75$ & Rp. 702.945,75 \\
\hline 2. & 2007 & Rp. $179.713 .497,00$ & Rp. 8.985.674,85 & Rp. $1.956 .216,10$ \\
\hline 3. & 2008 & Rp. $236.626 .920,00$ & Rp.11.831.346,00 & Rp. 2.845.671,15 \\
\hline 4. & 2009 & Rp. 282.602.520,00 & Rp.14.130.126,00 & Rp. 2.298.780,00 \\
\hline 5. & 2010 & Rp. $287.924 .760,00$ & Rp.14.396.238,00 & Rp. 266.112 \\
\hline
\end{tabular}

Sumber : DPKKA Kabupaten Sintang.

Pemberian uang perangsang atau yang lebih dikenal dengan remunerasi adalah semua bentuk imbalan yang diterima pegawai atas kontribusi yang diberikan kepada organisasi bersifat langsung atau tidak langsung, berbentuk cash ataupun in-kind diberikan secara reguler ataupun pada waktuwaktu tertentu.

Sumber daya menurut Van Meter dan Van Horn sebagaimana dikutif Winarno (2002:112) adalah sumber kebijakan yang mencakup dana atau perangsang (incentive) yang mendorong dan memperlancar proses inmplenetasi secara efektif. Tipe dan tingkatan sumber-sumber akan mempengaruhi komunikasi dan kegiatan-kegiatan pelaksana, mempengaruhi kecenderungan (disposisi) para pelaksana, serta mempengaruhi kondisi sosial ekonomi dan politik organisasi pelaksana seperti motivasi, ekonomi, dan tuntutan peran serta. Van Meter dan Van Horn (1974:465) mengemukakan sumber daya kebijakan (polyce resources)tidak kalah penting dengan standar dan tujuan. Sebagaimana yang dikemukakan Derthick dalam Van Meter dan Van Horn (1974:465)\| new towns study suggest that the limited supply of federal incentives was a majorcontributor to the failure of the program”.

\section{Karakteritik Organisasi Pelaksana.}

Karakteristik agen pelaksana, untuk suatu kebijakan publik yang ditetapkan oleh pemerintah selalu dikaitkan dengan struktur birokrasi. Beberapa unsur yang mempengaruhi dalam mengimplementasikan kebijakan berupa: kompetensi dan ukuran staf, tingkat pengawasan hirarki terhadap sub unit dan proses dalam badan pelaksana, sumber politik organisasi, vitalitas suatu organisasi dan jaringan kerja secara horisontal dan vertikal, kaitan formal dan informal suatu badan dengan pembuat keputusan. Keterkaitan antara Visi dan Misi tersebut dalam dokumen rencana kerja 
Dinas Pendapatan Pengelolaan Keuangan dan Aset Daerah (DPPKA) tergambar dalam suatu bagan sebagai berikut

\section{KETERKAITAN VISI DAN MISI DINAS PENDAPATAN, PENGELOLAAN KEUANGAN DAN ASET KABUPATEN SINTANG}

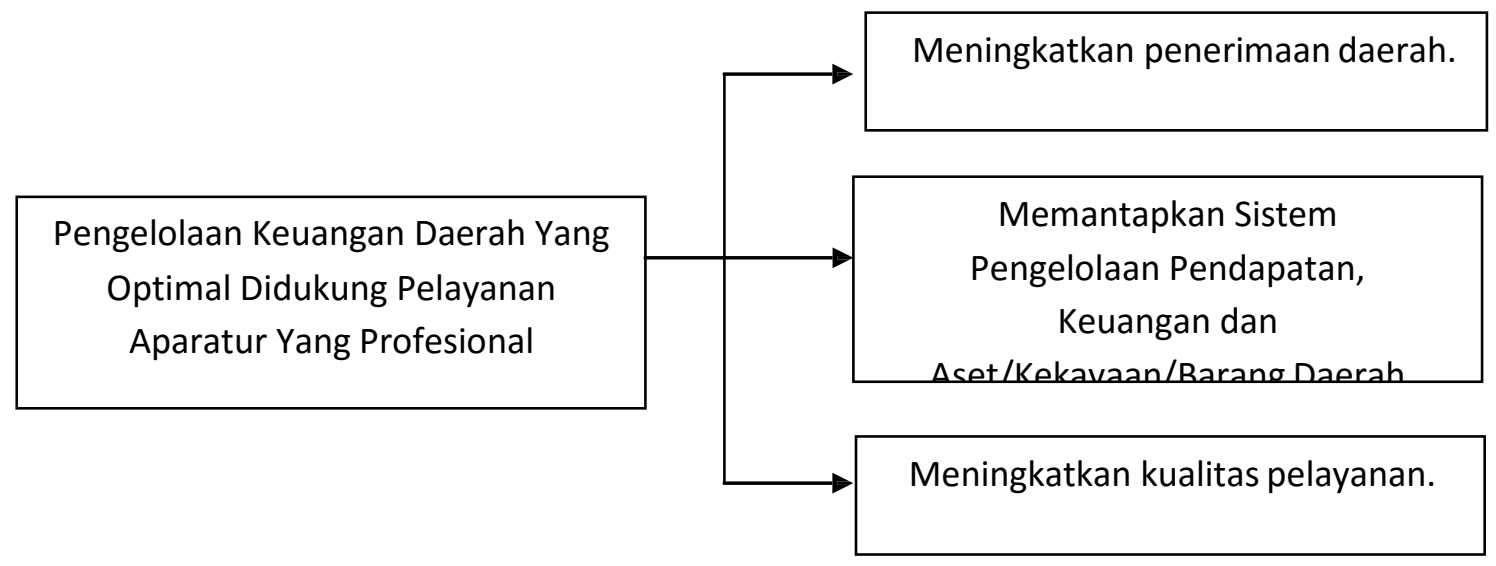

\section{Komunikasi antar Organisasi Terkait dan Kegiatan-Kegiatan Pelaksana}

Kebijakan publik akan dapat di implementasikan dengan baik dan terlaksana dengan efektif jika standar dan tujuan dikomunikasikan kepada pelaksana. Komunikasi yang dilakukan kepada pelaksana (implementors) sesuai dengan sasaran akan memberikan informasi yang bermanfaat terutama dalam menginterpretasikan kebijakan.

Bentuk dari informasi yang dilakukan adalah pembinaan yang dilakukan dalam bentuk sosialisasi tentang Peraturan Daerah, terutama tentang kewajiban yang harus dipenuhi wajib pajak seperti mengisi data dalam Surat Pemberitahuan Pajak Daerah (SPTPD), yang digunakan untuk melaporkan perhitungan dan atau pembayaran pajak daerah. Komunikasi antar organisasi dilakukan secara internal dalam hal pemungutan Pajak Hotel dan Penginapan, Komunikasi yang dilakukan oleh Kepala Bidang Pendapatan sesuai tugas pokok dan fungsi melakukan komunikasi internal dengan Seksi Pendaftaran dan Pendataan, Seksi Penetapan, dan Seksi penagihan. Komunikasi eksternal dilakukan oleh masing-masing seksi dengan subyek Pajak Hotel dan Penginapan.

Melakukan komunikasi dalam rangka koordinasi untuk pelaksanaan tugas dan fungsi dalam suatu organisasi merupakan suatu tugas yang tidak mudah dilakukan. Hal ini dikarenakan komunikasi tidak hanya menyangkut pada capaian penyampaian tujuan, tetapi yang terpenting adalah efek dari komunikasi yang diberikan. Sebagaimana pendapat Forsyth (1998:7) untuk mencapai tujuan komunikasi ada empat tujuan yang perlu dipahami yaitu: (1) mendengarkan apa yang diutarakan (untuk melihat apa yang anda perhatikan). (2) memahami apa yang mereka dengar atau lihat. (3) menyetujui apa yg mereka dengar (atau tidak menyetujui setelah memahami benar apa yang anda katakan atau perhatikan. (4) mengambil tindakan yang sesuai dengan tujuan secara keseluruhan dan yang dapat mereka terima.

Komunikasi internal yang dilakukan baik dengan atasan yakni Kepala Dinas DPKKA Kabupaten Sintang maupun dengan bawahan yakni Kepala Seksi Pendaaftaran dan Pendataan, Kepala Seksi Penetapan dan Kepala Seksi Penagihan serta staf pelaksana masing-masing seksi yang ada dilakukan melalui komunikasi formal dengan mengadakan rapat bersama untuk membahas pelaksanaan kegiatan pemungutan Pajak Hotel dan Penginapan. Hasil rapat dijadikan program yang akan dikembangkan dalam tahapan pelaksanaan pemungutan pajak. Setiap permasalahan dan kendala yang dihadapi dalam melakukan kegiatan pemungutan Pajak Hotel dan Penginapan, selalu 
diupayakan dengan memecahkan persoalan dengan melakukan sharing pendapat, yang dapat dijadikan sebagai informasi untuk mengatasi masalah yang kemungkinan dihadapi pada masa yang akan datang.

Komunikasi yang dilakukan mencakup transformasi informasi dan kejelasan serta konsistensi. Transformasi informasi tidak hanya berlaku kepada pelaksana kebijakan akan tetapi juga kelompok sasaran (target group). Target Group (kelompok sasaran) menurut Tachjan (2008:35) yaitu sekelompok orang atau organisasi dalam masyarakat yang akan menerima barang dan jasa atau yang akan dipengaruhi perilakunya oleh kebijakan. Mereka diharapkan dapat menerima dan menyesuaikan diri terhadap pola-pola interaksi yang ditentukan oleh kebijakan.

\section{Sikap Pelaksana}

Dalam hal pemungutan pajak Hotel dan Penginapan di Kabupaten Sintang pelaksananya adalah seluruh staf birokrasi yang ada di Dinas Pendapatan, Pengelolaan Keangan dan Aset Daerah, sesuai dengan tugas dan fungsi yang telah ditetapkan dalam organisasi.

Pelaksana kebijkan pemngutan Pajak Hotel dan Penginapan adalah seluruh staf yang berada dibawah Kepala Bagian Pendapatan DPKKA Kabupaten Sintang yang berjumlah 8 (delapan) orang. Dalam menjalankan tugas masing-masing mendapat surat tugas sebagai pelaksana pemungutan pajak. Secara operasional yang bertanggung jawab langsung dilapangan adalah Kepala Seksi Penagihan.

\section{Kondisi Ekonomi, Sosial dan Politik}

Kondisi lingkungan ekonomi, sosial dan politik dapat mempengaruhi pelaksanaan implementasi kebijakan yang telah ditetapkan dapat berhasil sesuai yang diharapkan atau sebaliknya menjadi penghambat dalam pelaksanaan implementasi kebijakan. Salah satu indikator kemajuan daerah dapat dilihat dari perekonomian.

Berdasarkan data Sekunder yang penulis dapatkan dari Dinas Pendapatan Pengelolaan Keuangan dan Aset Daeah (DPPKA) Kabupaten Sintang diperoleh informasi, pertumbuhan ekonomi pada tahun 2011 sebesar 7,26\%. Pertumbuhan ekonomi tersebut antara lain disebabkan mulai bangkitnya sektor rill seperti sektor industri pengolahan, sektor keuangan, pemerintahan dan jasa perusahaan serta sektor jasa. Sektor pertanian tetap menjadi andalan perekonomian Kabupaten Sintang dengan kontribusi 48,23\%, sektor lainnya yang memberikan kontribusi cukup tinggi antara lain sektor perdagangan, hotel dan restoran sebesar 22,64\%, sektor jasasebesar 7,11\%, sektor pertambangan dan penggalian sebesar 5,49\%, sektor industri pengolahan sebesar 5,49\%, sedangkan sektor lainnya masih dibawah $5 \%$.

Pertumbuhan sektor ekonomi yang baik dipengaruhi kebijakan-kebijakan sektoral yang mendorong terciptanya iklim usaha yang sehat yang pada gilirannya akan meningkatkan kegiatan ekonomi masyarakat. Berbagai kebijakan yang dilakukan oleh Pemerintah Daerah Kabupaten Sintang untuk meningkatkan kesejahteraan masyarakat dilakukan dengan memperluas penciptaan dan pemertaan lapangan kerja.

Peningkatan penciptaan kesempatan kerja terutama di sektor perkebunan dan pertanian diharapkan mampu mengatasi permasalahan sosial ekonomi masyarakat, yang diharapkan akan dapat terus mendukung laju peningkatan kesempatan kerja di sektor pertanian dan perkebunan. Hal ini diperkiraan akan tetap meningkat sejalan dengan pertumbuhan sektor pertanian yang diupayakan adanya perluasan lahan pertanian dan perkebunan, baik milik masyarakat maupun perusahanperusahaan swasta di bidang perkebunan Kelapa Sawit dan tanaman Karet. Peningkatan tersebut diharapkan mampu menekan angka pengangguran di Kabupaten Sintang. 
Kondisi sosial budaya di Kabupaten Sintang dapat diamati pada berbagai bidang kehidupan diantaranya adalah kesehatan, pendidikan dan pariwisata. Dalam bidang kesehatan umur harapan hidup masyarakat Kabupaten Sintang yaitu 66,6 tahun. Dalam bidang pendidikan angka melek huruf yaitu 83,60\%. Di bidang pariwisata dilihat dari potensinya Kabupaten Sintang merupakan daerah yang memiliki keberagaman potensi pariwisata karena terdapat beberapa objek wisata yang sangat prospektif untuk dikembangkan. Beberapa potensi pariwisata tersebut di antaranya adalah : Hutan Wisata Alam Baning, Hutan Wisata Bukit Kelam, Air Terjun Nokan Nayan, Museum Dara Juanti, Rumah Betang dan Upacara Adat.

\section{Kesimpulan}

Berdasarkan perumusan masalah, hipotesis dan hasil penelitian serta pembahasan mengenai Implementasi Kebijakan Pemungutan Pajak Hotel dan Penginapan di Kabupaten Sintang Provinsi Kalimantan Barat, maka dapat disimpulkan hal-hal sebagai berikut :

1. Implementasi kebijakan pemungutan pajak hotel dan penginapan yang di atur dalam Peraturan Daerah Kabupaten Sintang Nomor 5 Tahun 2003, memiliki standar dan sasaran yang jelas, akan tetapi tidak semua ketentuan yang ada dalam peraturan tersebut dapat dilaksanakan sepenuhnya sesuai ketentuan yang berlaku. Hal ini disebabkan kondisi objek pajak hotel dan penginapan yang ada, mengakibatkan Kepala Daerah harus membuat kebijakan lain untuk pelaksanaan pemugutan pajak hotel dan penginapan. Sumber daya (resourcers) yang terbatas terutama petugas pemungut pajak, serta sarana dan prasarana yang masih kurang menyebabkan pelaksanaan pemungutan pajak tidak dapat dilaksanakan sesuai ketentuan. Organisasi pelaksana dalam pemungutan pajak hotel dan penginapan ditunjuk dengan SK Bupati dalam SOTK, organisasi pelaksana tersebut adalah DPKKA Kabupaten Sintang. Secara operasional yang melaksanakan kebijakan tersebut adalah Kepala Dinas, Kepala Bagian Pendapatan, Seksi Pendaftaran dan Pendataan, Seksi Penetapan, dan Seksi Penagihan serta seluruh staf yang berada pada Bagiaan Pendapatan. Komunikasi antar organisasi terkait dan kegiatan-kegiatan pelaksana, dilakukan secara internal dan eksternal belum terlaksana secara maksimal. Sikap Para Pelaksana dalam menjalankan tugas sebagaimana yang telah digariskan dalam tugas dan fungsi untuk Bagian Pendapatan dan Seksi Pendaftaran dan Pendataan, Seksi Penetapan, Seksi Penagihan serta seluruh staf yang ada pada Bagian Pendapatan DPPKA Kabupaten Sintang dalam menjalankan tugas sudah cukup baik, meskipun demikian hasil yang diperoleh dari pemungutan pajak belum optimal. Lingkungan Sosial Ekonomi dan Politik juga sangat mendukung, dimana tingkat pertumbuhan ekonomi yang cukup baik, sosial kemasyarakatan dan partisipasi politik dari masyarakat, menunjukan jika lingkungan sosial ekonomi dan politik di kabupaten Sintang cukup stabil sehingga pelaksanaan implementasi kebijakan pemungutan pajak hotel dan penginapan dapat berjalan sesuai ketentuan yang berlaku, meskipun hasil pemungutan pajak belum maksimal.

2. Dengan demikian peneliti telah menemukan konsep baru dalam implementasi kebijakan pemungutan pajak diperlukan sistem kerja, tata kerja dan prosedur kerja yang merupakan bagian dari variabel Standar dan Sasaran kebijakan sebagaimana model yang ada pada teori Van Meter dan Van Horn untuk mendukung terlaksananya implementasi kebijakan. 


\section{DAFTAR PUSTAKA}

Agustino. L. 2006. Politik dan Kebijakan Publik. Bandung.Asosiasi Ilmu Politik Indonesia (AIPI) Bandung Bekerja sama dengan Puslit KP2W Lembaga Penelitian Unpad.

Albrow, Martin. 1996. Birokrasi. Penerjemah : M.RusliK. dan Totok Daryanto. Yogyakarta: Tiara Wacana

Anderson,J.E. 2003. Public Policy Making. An Introduction,3 ed. Boston New York.Hougton Mifflin Company.

Bawazir, F, 1996. Pungutan Pada Dunia Usaha, dalam seri Kajian Fiskal Moneter N0.19/VIII/1996, Pusat Pengkajian Fiskal dan Moneter. Jakarta: CFMS

Blau, Peter M and Marshall W. Mayer, 2000. Birokrasi Dalam Masyarakat Modern. Penerjemah : Riyanto Slamet. Jakarta: Prestasi Pustaka Raya

Bogdan, Robert C. And Biklen.1993. Terjemahan Arif Fucrahman, Dasar-Dasar Penelitian Kualitatif, Surabaya : Usaha Nasional.

Devas, N, dkk. 1989. Keuangan Pemerintah Daerah di Indonesia, terjemahan Masri Marimis. Jakarta: UI-Press

Donald S. Van Meter dan Carl E. Vanhorn.1975. The Policy Implementation Process, A Conceptual Framework. Departement of Political Science Ohio State University.

Frans Poels.1997. Job Evaluation and Remunerations Strategies. London: British Library.

Ganna, Judistira K. 1999. Metode Penelitian : Pendekatan Kualitatif, Bandung: Primaco Akademika

Grindle,M.1980. Politics and Policy Implementations, In The Third World,New Jersey: Precenton University Press

Hadisoeprapto. 1996. Pengantar Tata Hukum Indonesia. Yogyakarta: Liberty

Ichsan, C. 1996. Pengembangan Pendapatan Asli Daerah (PAD). Banda Aceh: UP3R-FE Universitas Syah Kuala.

Ismail, T. 2008. Pengantar Pajak Daerah di Indonesia. Jakarta : Yellow Printing.

Jones, Charles O.1984. An Introduction to the study of Public Policy. Thrid Edition Monterey, California Books/Cole Publishing Company.

Judisseno, Rimsky,K. 2005. Pajak dan Strategi Bisnis Suatu Tinjauan Tentang Kepastian Hukum dan Penerapan Akuntansi di Indonesia. Jakarta : Gramedia Pustaka Utama

Lains, A. 1985. Pendapatan Daerah dalam Ekonomi-Orde Baru, dalam Prisma No.4 April 1985, LP3ES, Jakarta Hal 40-57

Lubis, S, M. 1975. Pergeseran Politik dan Perundang-Undangan Mengenai Pemerintah Daerah. Bandung : Alumni

Mardiasmo.2006. Perpajakan Edisi Revisi. Yogyakarta : ANDI

-2004. Otonomi dan Manajemen Keuangan Daerah. Yogyakarta: ANDI

Martodirdjo. 1991. Metode Penelitian Kualitatif. Bandung: Bina Rosda Karya

Milles, B,M. Dan Huberman.1992. Analisis Data Kualitatif. Bandung : Bina Rosda Karya

Moleong,Lexy. 2000. Metode Penelitian Kualitatif. Bandung : PT Remaja Rosda Karya 
Nasution. S. 1996. Metode Penelitian Naturalistik Kualitatif, Bandung : Tarsito

Nawawi, H. 1991. Metode Penelitian Bidang Sosial. Yogyakarta : Gajahmada University

Press. Ndraha, Taliziduhu.1989. Konsep Administrasi dan Administrasi di Indonesia.

Jakarta : Bina

Aksara

Nugroho, R. 2008. Public Policy.Teori Kebijakan-Analisis Kebijakan-Proses Kebijakan Perumusan, Implementasi, Evaluasi, Revisi Risk Management Dalam Kebijakan Publik Kebijakan Sebagai The Fifth Estate-Metode Penelitian Kebijakan. Jakarta: PT. Elex Media Komputindo Kelompok Gramedia.

Redjo, Ibnu. 1995. Intensifikasi dan Eksistensifikasi Peningkatan PAD, Mimeo, Makalah Pada Seminar Otonomi Daerah Dati II, Riau Bangkiang.

Rosdiana, Haula dan Irianto, Slamet E. 2011. Panduan Lengkap Tata Cara Perpajakan di Indonesia. Jakarta : Visimedia.

Snavely. Keith. Innovations in State Tax Administration. Source: Public Administration Review, Vol 48,N0.5 (sep-Oct.,1988), pp.903-910 Published by : Black well Publishing on behalf of the American Society for Public Administration. Stable http:/www.jstor.org/stable/976906 Accessed:27/04/2009 05:52

Soedjadi.FX. 1989. O \& M, Organization and Methods Penunjang Berhasilnya Proses

Manajemen. Jakarta : CV.Haji Masagung.

Steers, Richard. 1985. Efektivitas Organisasi. Penterjemah Magdalena Jamin. Jakarta:

Erlangga Suhadak dan Nugroho, T. 2007. Paradigma Baru Pengelolaan

Keuangan Daerah dalam

Penyusunan APBD di Era Otonomi. Malang : Banyu Media Publishing

Suryaningrat, Bayu.1981. Pemerintahan, Administrasi Desa dan Kelurahan, Jakarta :

Aksara Baru. Syamsi. I. 1988. Dasar-Dasar Kebijakan Keuangan Negara. Jakarta : Bina

Aksara

Tachjan.H. 2006. Implementasi Kebijkan Publik. Bandung. Puslit KP2W.Lembaga Penelitian Unpad.

Tengkilisan, Hessel Nogi S. 2003. Kebijakan Publik yang Membumi. Yogyakarta. Yayasan Pembaharuan Administrasi Publik dan Lukman Ofset.

Widodo.J.2001. Good Governance. Telaah dari Dimensi Akuntabilitas dan Kotrol Birokrasi pada Era Desentralisasi dan Otonomi Daerah. Surabaya. Insan Cendekia.

Winarno.B. 2002. Teori dan Proses Kebijakan Publik. Yogyakarta. Media Press. 